Article

\title{
Development of an ImmunoFET for Analysis of Tumour Necrosis Factor- $\alpha$ in Artificial Saliva: Application for Heart Failure Monitoring
}

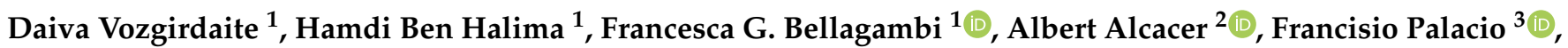

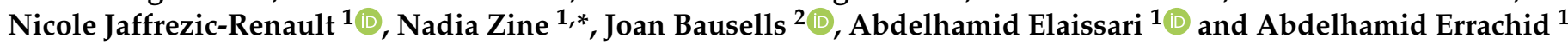 \\ 1 Institut de Sciences Analytiques (ISA)-UMR 5280, Université Claude Bernard Lyon 1, 5 rue de la doua, \\ 69100 Lyon, France; daiva.vozgirdaite@insa-lyon.fr (D.V.); hamdi.ben-halima@isa-lyon.fr (H.B.H.); \\ francesca.bellagambi@univ-lyon1.fr (F.G.B.); nicole.jaffrezic@univ-lyon1.fr (N.J.-R.); \\ abdelhamid.elaissari@univ-lyon1.fr (A.E.); abdelhamid.errachid-el-salhi@univ-lyon1.fr (A.E.) \\ 2 Institute of Microelectronics of Barcelona (IMB-CNM, CSIC), Campus UAB, Bellaterra, \\ 08193 Barcelona, Spain; albert.alcacer@imb-cnm.csic.es (A.A.); joan.bausells@imb-cnm.csic.es (J.B.) \\ 3 Department of Electronics and Biomedical Engineering, Faculty of Physics, University of Barcelona, \\ Martíi Franquès 1, 08028 Barcelona, Spain; francisco.palacio@ub.edu \\ * Correspondence: nadia.zine@univ-lyon1.fr; Tel.: +33-601165140
}

\section{check for}

updates

Citation: Vozgirdaite, D.; Ben Halima, H.; Bellagambi, F.G; Alcacer, A.; Palacio, F.; Jaffrezic-Renault, N.; Zine, N.; Bausells, J.; Elaissari, A.; Errachid, A. Development of an ImmunoFET for Analysis of Tumour Necrosis Factor- $\alpha$ in Artificial Saliva: Application for Heart Failure

Monitoring. Chemosensors 2021, 9, 26. https://doi.org/10.3390/

chemosensors 9020026

Academic Editor: Francesco Baldini Received: 29 December 2020

Accepted: 25 January 2021

Published: 29 January 2021

Publisher's Note: MDPI stays neutra with regard to jurisdictional claims in published maps and institutional affiliations.

Copyright: (c) 2021 by the authors. Licensee MDPI, Basel, Switzerland. This article is an open access article distributed under the terms and conditions of the Creative Commons Attribution (CC BY) license (https:// creativecommons.org/licenses/by/ $4.0 /)$.

\begin{abstract}
Assessing tumour necrosis factor- $\alpha$ (TNF- $\alpha)$ levels in the human body has become an essential tool to recognize heart failure (HF). In this work, label-free, rapid, easy to use ImmunoFET based on an ion-sensitive field effect transistor (ISFET) was developed for the detection of TNF- $\alpha$ protein. Monoclonal anti-TNF- $\alpha$ antibodies (anti-TNF- $\alpha \mathrm{mAb}$ ) were immobilized on an ISFET gate made of silicon nitride $\left(\mathrm{Si}_{3} \mathrm{~N}_{4}\right)$ after salinization with 11-(triethoxysilyl) undecanal (TESUD). The obtained ISFET functionalized with the mAbs (ImmunoFET) was used to detect TNF- $\alpha$ protein in both phosphate buffer saline (PBS) and artificial saliva (AS). The change in the threshold voltage of the gate $\left(\Delta \mathrm{V}_{\mathrm{T}}\right)$ showed approximately linear dependency on the concentration of the antigens in the range 5-20 pg/mL for both matrixes. The cross-selectivity study showed that the developed ImmunoFET demonstrated to be selective towards TNF- $\alpha$, when compared to other HF biomarkers such as N-terminal pro-brain natriuretic peptide (NT-proBNP), interleukin-10 (IL-10), and cortisol, even if further experiments have to be carried out for decreasing possible unspecific absorption phenomena. To the best of our knowledge, this is the first ImmunoFET that has been developed based on $\mathrm{Si}_{3} \mathrm{~N}_{4}$ for TNF- $\alpha$ detection in AS by electrical measurement.
\end{abstract}

Keywords: ImmunoFET; tumour necrosis factor- $\alpha$; heart failure; saliva analysis; TESUD

\section{Introduction}

A decrease in the performance of the heart to pump and/or fill with blood is commonly known as heart failure (HF). Many different factors such as cardiac abnormalities (e.g., structural abnormalities including stiffness of ventricular chamber, functional abnormalities including mitral incompetence, etc.), coexisting conditions (e.g., diabetes, anaemia, sleep apnoea, etc.), or other factors (e.g., age, genetic influence, life style, etc.) can add up to the cause of HF [1,2]. Statistics show that approximately 26 million people worldwide are affected by HF [3], which causes high mortality rates of hospitalized elderly patients [4] and larger health expenditure. With the increasing prevalence of this cardiac syndrome $[3,4]$, effective and early diagnosis is needed. While there are some distinct symptoms of HF, such as oedema (swelling due to fluid entrapment in the body), dyspnoea (shortness of breath), which is observed in most of the patients just before hospitalization, they are attributed to acute decompensated HF, which is a sudden aggravation of HF [5]. However, before the worsening of symptoms, HF frequently has nonspecific symptoms, making it challenging to detect it in its early stages, which is why the detection of specific biomarkers 
related to HF diagnosis became one of the most used methods in determining the early signs of HF. These biomarkers provide the ability not only to diagnose HF, but also to monitor the course of the therapy [6]. Tumour necrosis factor- $\alpha$ (TNF- $\alpha$ ) is a biomarker linked to left ventricular dilation [6]. TNF- $\alpha$ is a pro-inflammatory cytokine found to be higher in patients with chronic HF, when first measured in the early 1990s [7]. With the increasing release of this biomarker, HF progresses as well. Thus, monitoring the amount of TNF- $\alpha$ proteins in the patients can be helpful to monitor the course of the HF [8]. Among the most common sensing systems for biomarker detection is the enzyme-linked immunosorbent assay (ELISA), well known in a wide range of medical applications in diagnostics [9]. While this technique can be easily used for TNF- $\alpha$ detection, ELISA and other assays such as radioimmunoassay (RIA) have principal limitations, such as high costs, long run-time, requirement of specialized technical skills, no possibility to perform real-time measurement, and other disadvantages briefly summarised in a review article by Mazarin de Moraes and Kubota [10]. Affinity sensors, which are analytical devices designed to detect the interaction between a specific recognition system (antibody, $\mathrm{Ab}$ ) and analyte (antigen, Ag) and convert it into a measurable signal [11,12] (either electrical, thermometric or optical) are already widely used as sensing platforms in many different fields, including the medicine, agriculture, and food industries [13]. In this regard, different techniques were used for the detection of TNF- $\alpha$ such as piezoelectric biosensors [14], difference pulse voltammetry [15], chronoamperometry [11,16], electrochemical impedance spectroscopy [17], Mott Schottky [18], etc. On the other hand, immunosensors (which allow us to obtain measurable signal due to the changes in biomarker concentration) based on ion-sensitive field effect transistors (ISFET) with functionalized antibodies on the gate surface (referred as ImmunoFET), are an attractive, direct, label-free alternative for the detection of different biomarkers in biological fluids [19]. The principle of ImmunoFET is based on the alteration of the potential on the gate surface due to the interaction between biological recognition system, which is bonded to the gate surface, and the analyte $[10,20]$. These ImmunoFETs show high sensitivity [21-23], reaching detection limits for some pro-inflammatory cytokines as low as $10-100 \mathrm{fg} / \mathrm{mL}$ [23], as well as good selectivity [24].

Moreover, the measurements with ISFET do not require professional personnel to perform the detection, making them uncomplicated to use, and they can be easily integrated into electronic chips [10] as well as in the emerging lab-on-chip (LoC) and point-of-care (PoC) technologies [25,26]. In this study, we focused on the development of ImmunoFET for the detection of TNF- $\alpha$ protein considering saliva analysis as the final aim, as various cytokines, including TNF- $\alpha$ protein, can be found in saliva $[27,28]$. Since saliva reflects the biological activity as well as the health status, saliva analysis offers several advantages if compared with the traditional blood analyses (e.g., non-invasive sampling, easily and unobtrusive collection, potential for real-time monitoring, minimal risk of cross-contamination, more economical sampling, shipping, and storage compared to serum) [17,29-33]. The prepared sensors were studied for the sensitivity as well as for the selectivity for the detection of TNF- $\alpha$ in phosphate buffer saline (PBS) medium, by analysing standard solutions containing other HF biomarkers such N-terminal pro-brain natriuretic peptide (NT-proBNP), interleukin 10 (IL-10), and cortisol [34-39]. Moreover, preliminary analyses in artificial saliva were performed in order to investigate the effects of a different matrix.

\section{Materials and Methods}

\subsection{Materials and Chemicals}

Electrical measurements were performed using LabVIEW (v. 10.0) software. ISFET is connected to external chassis (National Instruments, PXI-1031) (connected to the personal computer), included with a digital multimeter and data acquisition module, through a shielded connector block (National Instruments, SCB-68). Wire bonding was performed using Kulicke\&Soffa 4523 A Digital instrument from Kulicke\&Soffa (Singapore). The solution $\mathrm{pH}$ was measured using a pH-meter: Mettler Toledo FE20/EL20. The UV/Ozone 
Procleaner ${ }^{\mathrm{TM}}$ (BioForce, Papenburg, Germany) was used in order to activate the ISFET's surface by creating $-\mathrm{OH}$ groups.

TNF- $\alpha$ (Cat. No. 210-TA-100), anti-TNF- $\alpha$ mAb (Cat. No. MAB610-500), IL-10 (Cat. No. 217-IL-050) were from R\&D Systems (BioTechne, Lille, France). Hydrocortisone (cortisol, purity 99\%, Cat. No. ab141250) was from abcam (Cambridge, UK). NT-proBNP (Cat. No. 8NT2) was from HyTest (Turku, Finland). Millipore Milli-Q nanopure water (resistivity $>18 \mathrm{M} \Omega \mathrm{cm}$ ) was produced by a Millipore Reagent Water System (Molsheim, France). 11-triethoxysilyl undecanal (TESUD, 90\%) was purchased from abcr (Karlsruhe, Germany). Pure ethanol (purity $98.0 \%$ ), cyanoborohydride $\left(\mathrm{NaBH}_{3} \mathrm{CN}\right)$, ethanolamine $\left(\mathrm{Et}-\mathrm{NH}_{2}\right)$, urea, mucin from porcine stomach, sodium phosphate dibasic $\left(\mathrm{Na}_{2} \mathrm{HPO}_{4}\right)$, anhydrous calcium chloride $\left(\mathrm{CaCl}_{2}\right)$, potassium chloride $(\mathrm{KCl})$, sodium chloride $(\mathrm{NaCl})$, sodium hydroxide $(\mathrm{NaOH})$, tris-(hydroxymethyl) methylamine, magnesium nitrate $\left(\mathrm{Mg}\left(\mathrm{NO}_{3}\right)_{2}\right)$, sodium bicarbonate $\left(\mathrm{NaHCO}_{3}\right)$, and phosphate buffer saline (PBS) tablets were purchased from Sigma-Aldrich (Lyon, France). PBS buffer used in this study was prepared by dissolving PBS tablets in the nanopure water as indicated by the supplier by yielding $0.01 \mathrm{M}$ phosphate buffer ( $\mathrm{pH} 7.4$ ) containing $0.0027 \mathrm{M}$ potassium chloride and $0.137 \mathrm{M}$ sodium chloride. Hydrochloric acid $(\mathrm{HCl})$ was purchased from VWR Prolabo Chemicals (Paris, France). Epoxy resin EPO TEK H70E2LC was from Epoxy Technology (Paris, France).

\subsection{Fabrication of the ISFET Devices}

The ISFET devices were fabricated as N-type FETs on $100 \mathrm{~mm}$ diameter silicon wafers, with a boron substrate doping of $10^{15} \mathrm{~cm}^{-3}$. First, a silicon dioxide layer was grown by wet oxidation with a thickness of $800 \mathrm{~nm}$. The oxide is patterned with photolithography and wet etching, and the source and drain regions of the ISFET are doped by ion implantation of phosphorus with a dose of $4.2 \times 10^{15} \mathrm{~cm}^{-2}$. The oxide layer was then eliminated from the gate region by photolithography and wet etching. The gate dielectric was added by growing a $78 \mathrm{~nm}$ thick silicon dioxide, followed by the deposition of a $100 \mathrm{~nm}$ thick silicon nitride layer by low-pressure chemical vapour deposition (LPCVD). The silicon nitride was eliminated from all areas except the gate by photolithography and dry reactive ion etching (RIE). This was followed by the opening of the contact windows by photolithography and RIE etching. The metal interconnect lines are made of $15 \mathrm{~nm}$ thick titanium plus $150 \mathrm{~nm}$ thick platinum, which were deposited by vacuum evaporation and patterned by photolithography plus lift-off. Finally, a passivation layer of $400 \mathrm{~nm}$ of silicon dioxide plus $400 \mathrm{~nm}$ of silicon nitride was deposited by plasma-enhanced chemical vapour deposition (PECVD). The passivation was patterned by photolithography plus RIE (for the silicon nitride) and wet etching (for the silicon dioxide) to open the gate area and the electrical contact pads. The gate area of the ISFETs had dimensions of $400 \times 20 \mu \mathrm{m}$.

To package the ISFETs devices for measurements in liquid solutions, the silicon wafer was diced, and the resulting chips were glued to a printed circuit board (PCB) using an epoxy resin. The electrical contact pads were wire-bonded to the PCB by using $25 \mu \mathrm{m}$ diameter aluminium wires. Finally, the bonding wires, the external areas of the chip and the electric tracks on the $\mathrm{PCB}$, were encapsulated by the same epoxy resin to protect them from the liquid solution (Figure 1). Finally, the reference electrode (RE) based on $\mathrm{Ag} / \mathrm{AgCl}$ was made by electrochemical deposition of $\mathrm{Ag}$ on one of microelectrode based on platinum, using sodium nitrate $\left(\mathrm{NaNO}_{3}\right)(1 \mathrm{M})$ and silver nitrate $\left(\mathrm{AgNO}_{3}\right)(25 \mathrm{mM})$ at $\mathrm{pH}$ 1. The deposited silver layer was chlorinated by overnight incubation of the RE in $\mathrm{HCl}(1 \mathrm{M})$ solution. A detailed process of RE fabrication can be found in previous work by our group [40,41]. 


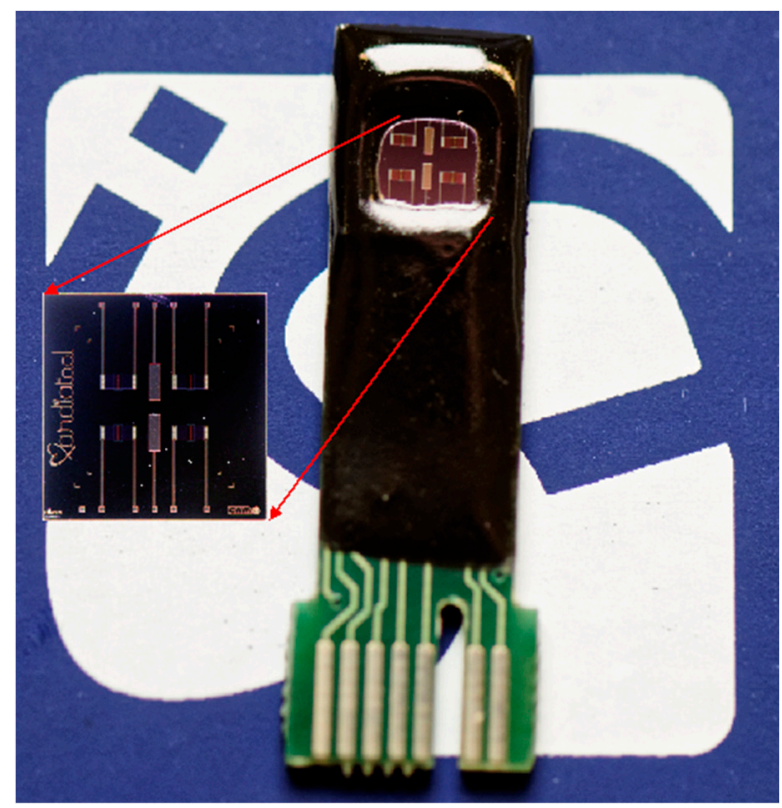

Figure 1. Photograph of the encapsulated chip containing four ion-sensitive field effect transistors (ISFETs), $\mathrm{Ag} / \mathrm{AgCl}$ reference microelectrode and Pt counter microelectrode.

\subsection{Functionalization of ISFET Surface with Antibodies}

Before the functionalization, the chip, containing four working ISFETs, was thoroughly rinsed with ultrapure water and dried using nitrogen gas $\left(\mathrm{N}_{2}\right)$ flow. The ISFET was then placed in a UV/Ozone ProCleaner ${ }^{\mathrm{TM}}$ for $45 \mathrm{~min}$ to remove any remaining organic contaminants as well as to activate the surface of the gate made of silicon nitride $\left(\mathrm{Si}_{3} \mathrm{~N}_{4}\right)$ with hydroxyl groups (-OH). Afterwards, the surface was functionalized with 11-(triethoxysilyl) undecanal (TESUD) using the vapour phase method: ISFET with activated surface was placed inside a desiccator that was saturated with TESUD [42-45] for $45 \mathrm{~min}$. Later, the sample was placed inside a furnace $\left(100^{\circ} \mathrm{C}\right)$ for $1 \mathrm{~h}$ to ensure TESUD adhesion onto the gate surface of ISFET through the hydroxyl groups, followed by cleaning in pure ethanol to remove excess TESUD. The ISFET was then covered with $10 \mu \mathrm{g} / \mathrm{mL}$ anti-TNF- $\alpha$ mAbs diluted in a mixture of a $10 \mathrm{mM}$ phosphate buffer saline (PBS) pH 7.4 and $4 \mathrm{mM}$ sodium cyanoborohydride $\left(\mathrm{NaBH}_{3} \mathrm{CN}\right)$ in PBS and left overnight for $\mathrm{mAbs}$ immobilization during which Abs covalently bond to TESUD. Finally, after removal of the excess solution of mAbs by cleaning the chips with PBS and drying with $\mathrm{N}_{2}$ flow, unreacted chains of TESUD were capped by the addition of ethanolamine $\left(\mathrm{Et}-\mathrm{NH}_{2}\right)$. Briefly, the surface of ISFET with immobilized mAbs (ImmunoFET) was covered with 1\% of Et-NH2 diluted in the previously mentioned mixture of $4 \mathrm{mM} \mathrm{NaBH}{ }_{3} \mathrm{CN}$ in PBS for $30 \mathrm{~min}$, after which the ISFET was once again cleaned and dried using $\mathrm{PBS}$ and $\mathrm{N}_{2}$ flow and afterwards placed into containers with PBS solution for storage at $4{ }^{\circ} \mathrm{C}$.

\subsection{Preparation of Artificial Saliva (AS)}

Artificial saliva (AS) was prepared as described elsewhere $[11,16,17]$. Briefly, AS preparation was carried out by dissolving $4 \mathrm{mg} / \mathrm{mL}$ of urea, $4 \mathrm{mg} / \mathrm{mL}$ of mucin from porcine stomach, $0.6 \mathrm{mg} / \mathrm{mL}$ of sodium phosphate dibasic $\left(\mathrm{Na}_{2} \mathrm{HPO}_{4}\right), 0.3 \mathrm{mg} / \mathrm{mL}$ of sodium bicarbonate $\left(\mathrm{NaHCO}_{3}\right), 0.6 \mathrm{mg} / \mathrm{mL}$ of anhydrous calcium chloride $\left(\mathrm{CaCl}_{2}\right), 0.4 \mathrm{mg} / \mathrm{mL}$ of potassium chloride $(\mathrm{KCl})$, and $0.4 \mathrm{mg} / \mathrm{mL}$ of sodium chloride $(\mathrm{NaCl})$ in Millipore Milli-Q nanopure water (resistivity $>18 \mathrm{M} \Omega \mathrm{cm}$ ) produced by a Millipore Reagent Water System. Dissolving was aided by placing the solution in ultrasonic bath for $20 \mathrm{~min}$ to ensure the solution homogeneity. Afterwards, $0.1 \mathrm{M}$ of sodium hydroxide $(\mathrm{NaOH})$ was added into the solution to obtain $\mathrm{pH}$ with the value of 7.2 . The prepared AS was stored at $4{ }^{\circ} \mathrm{C}$ until further use. 


\subsection{Electrochemical Characterisation of ISFET}

To investigate the performance and sensitivity of ISFET before the functionalization with $\mathrm{mAbs}$, one ISFET was tested using different $\mathrm{pH}$ solutions. Briefly, $\mathrm{pH}$ of a mixture of $5 \mathrm{mM}$ of tris-(hydroxymethyl) methylamine and $0.4 \mathrm{M}$ of magnesium nitrate $\mathrm{Mg}\left(\mathrm{NO}_{3}\right)_{2}$ was measured using a $\mathrm{pH}$ meter. Afterwards, the solution was divided into three smaller ones. Their $\mathrm{pH}$ was adjusted using hydrochloric acid $(\mathrm{HCl})$ and then measured again, giving final values of $\mathrm{pH} 7.01,5.00$, and 3.26 .

Electrical measurements were performed using LabVIEW software. ISFET was connected to external chassis (National Instruments, PXI-1031) (connected to the personal computer), included with a digital multimeter and data acquisition module, through a shielded connector block (National Instruments, SCB-68) (See Figure 2). The reference voltages were applied using an $\mathrm{Ag} / \mathrm{AgCl}$ reference electrode, as described elsewhere [46,47]. The ISFET transfer characteristics (drain current, $\mathrm{I}_{\mathrm{DS}}$, vs. gate-to-source voltage, $\mathrm{V}_{\mathrm{GS}}$ ) were measured at a drain-to-source voltage $\left(\mathrm{V}_{\mathrm{DS}}\right)$ of $500 \mathrm{mV}$ varying the $\mathrm{V}_{\mathrm{GS}}$ from $-0.5 \mathrm{~V}$ to $1.5 \mathrm{~V}$ value and vice versa for $\mathrm{I}_{\mathrm{DS}}$ dependence on $\mathrm{V}_{\mathrm{DS}}$. Evaluations were performed minimum of 10 times on 4 ImmunoFET electrodes, during each experiment. After each experiment, the ISFET was cleaned with ultrapure water and carefully dried before immersing into solution with different analyte concentrations.

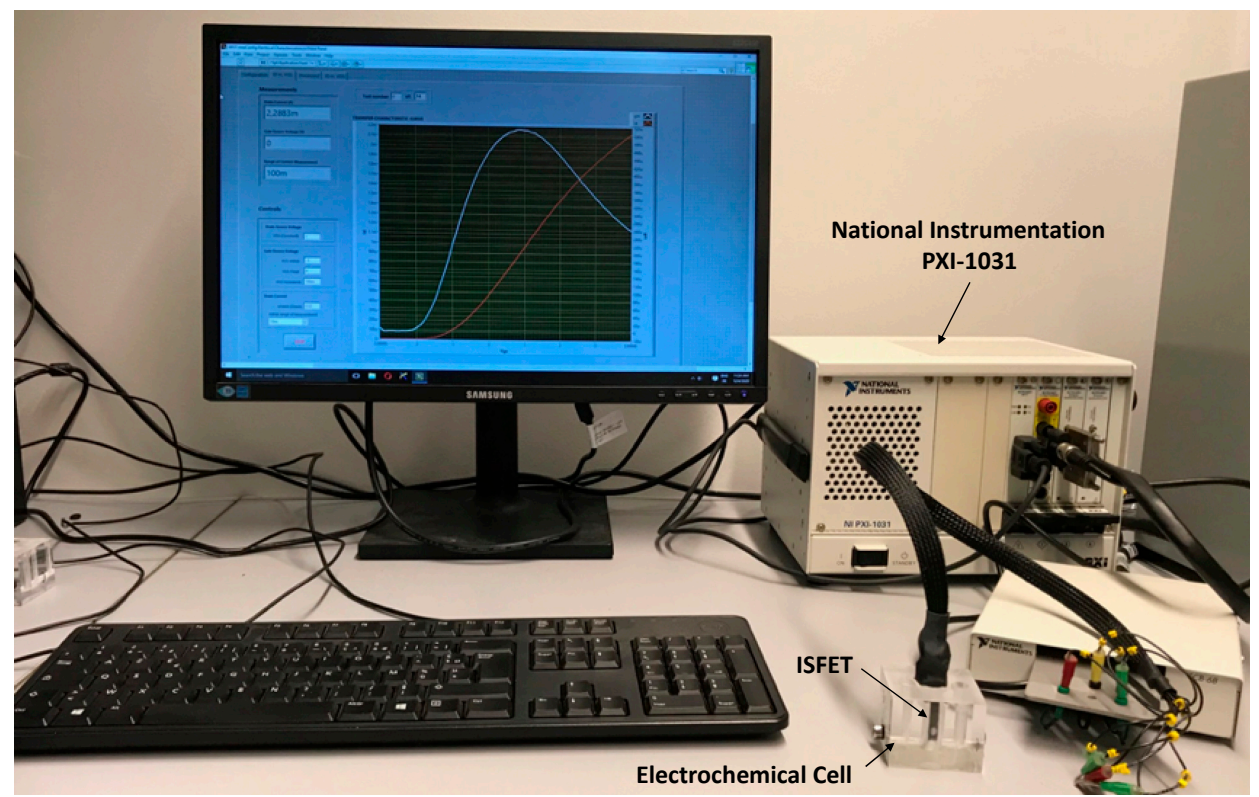

Figure 2. Measurement setup for testing ISFETs exposed to $\mathrm{pH}$ solution.

\subsection{Detection and Characterization of Antigens ( $A g$ ) Using ImmunoFET}

Detection of antigens was performed using the same characterization method and software as described before for $\mathrm{pH}$ measurement. The scheme of ImmunoFET is shown in Figure 3.

Various concentrations of TNF- $\alpha$ antigen (Ag) were tested: 5, 10, 15, $20 \mathrm{pg} / \mathrm{mL}$. Before each detection, ImmunoFET was dried with $\mathrm{N}_{2}$ flow and then incubated inside the solution of Ags with the required concentration at $4{ }^{\circ} \mathrm{C}$ for $30 \mathrm{~min}$. The ImmunoFET was then carefully washed with PBS solution and placed inside the beaker with $7 \mathrm{~mL}$ of PBS (pH 7.4) for analysis. The sensor was then rinsed with PBS, incubated with higher Ags concentration, and the signal was measured again. For the detection of TNF- $\alpha$ in AS (pH 7.2), the same steps were repeated, except for the dilution of TNF- $\alpha$ protein in AS instead of PBS. After the incubation of ImmunoFET in AS with Ags, the sensor was cleaned with PBS and then immerged into the beaker with PBS for the electrical measurements. TNF- $\alpha$ detection in both PBS and AS was assessed by performing measurements on three chips for each medium. For the interference study in PBS, different heart failure biomarkers were used: 
N-terminal pro-brain natriuretic peptide (NT-proBNP), cortisol, and interleukin-10 (IL-10). For each biomarker, a newly functionalised chip was used, as they are not reusable due to a strong Abs-Ags bond that it is difficult to break.

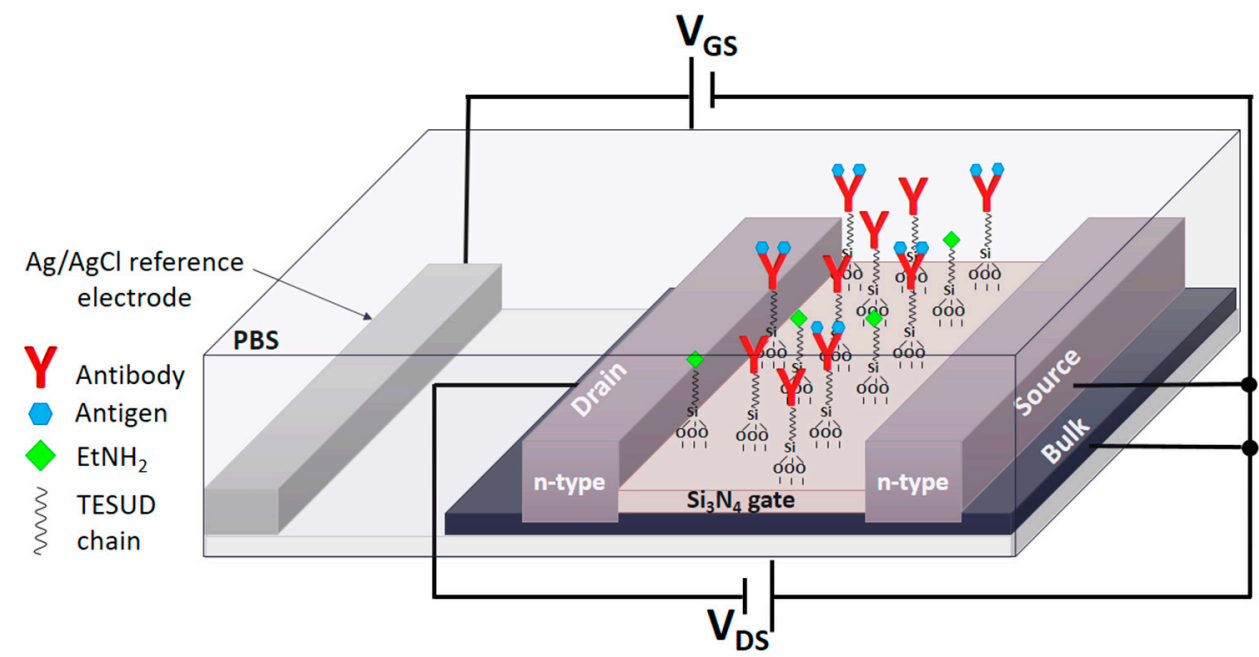

Figure 3. Schematic illustration of ImmunoFET device operating system with immobilized antibodies for antigen detection.

\section{Results and Discussion}

The electrical characterization has shown that all the ISFETs have good characteristics as field-effect transistors. The devices have shown good operating characteristics as shown in Figure 4. The drain current and the transconductance $\left(\mathrm{G}_{\mathrm{m}}\right)$ versus the gate-tosource voltage curves were shifted to positive bias as the $\mathrm{pH}$ increased (Figure $4 \mathrm{~A}$ ), with a threshold voltage $\left(\mathrm{V}_{\mathrm{T}}\right)$ of $52.5 \mathrm{mV} / \mathrm{pH}$ response that was obtained after the extraction of the $\mathrm{V}_{\mathrm{T}}$ vs. $\mathrm{pH}\left(\mathrm{S}=\Delta \mathrm{V}_{\mathrm{T}} / \Delta \mathrm{pH}\right)$. The $\mathrm{Si}_{3} \mathrm{~N}_{4}$ behaviour can be explained assuming that the insulator surface contains two different sites: $\mathrm{Si}-\mathrm{OH}$ groups, amphoteric sites, resulting from the oxidation of the surface and amine groups, $\mathrm{Si}-\mathrm{NH}_{2}$, that are basic sites [48]. On a completely oxygen-free $\mathrm{Si}_{3} \mathrm{~N}_{4}$ surface, each surface nitrogen can also be assumed to be bonded to three silicon atoms, forming a group with a lone electron pair on the nitrogen atom, $\mathrm{Si}_{3} \mathrm{~N}$. This group is similar to $\mathrm{z}$ tertiary amine in an organic compound. The electron pair on the nitrogen atom is the only one available for a hydrolysis reaction, which would proceed as follows:

$$
\mathrm{Si}_{3} \mathrm{~N}+\mathrm{H}_{2} \mathrm{O} \rightarrow \mathrm{Si}_{2} \mathrm{NH}+\mathrm{Si}-\mathrm{OH}
$$
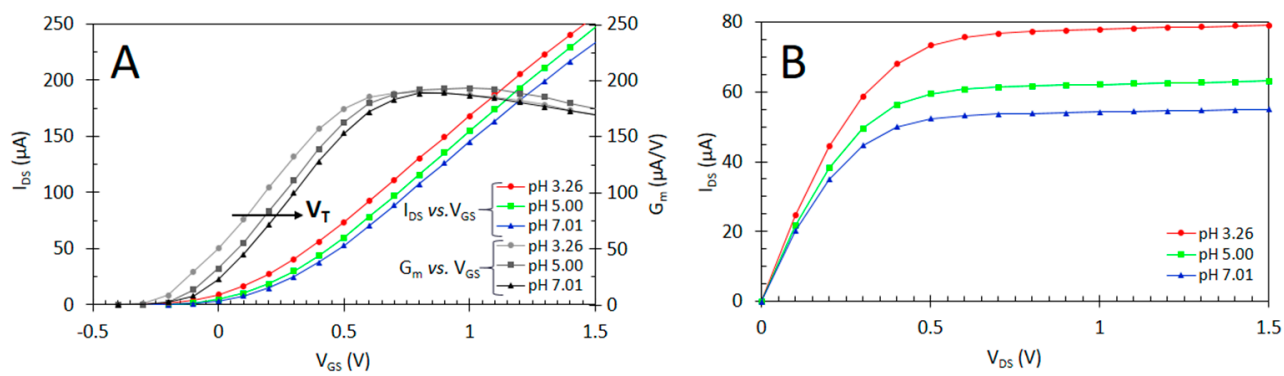

Figure 4. Influence of $\mathrm{pH}$ on ISFETs characteristics: (A) $\mathrm{I}_{\mathrm{DS}}$ vs. $\mathrm{V}_{\mathrm{GS}}, \mathrm{G}_{\mathrm{m}}$ vs. $\mathrm{V}_{\mathrm{GS}}$ at $\mathrm{V}_{\mathrm{DS}}=0.5 \mathrm{~V}$ and (B) $\mathrm{I}_{\mathrm{DS}} \mathrm{vs}$. $\mathrm{V}_{\mathrm{DS}}$ at $\mathrm{V}_{\mathrm{GS}}=0.5 \mathrm{~V}$ using Tris $/ \mathrm{HCl}$ buffer solutions at different $\mathrm{pH}$.

The secondary amine group can then be further hydrolysed to form a primary amine and another silanol group.

$$
\mathrm{Si}_{2} \mathrm{NH}+\mathrm{H}_{2} \mathrm{O} \rightarrow \mathrm{Si}-\mathrm{NH}_{2}+\mathrm{Si}-\mathrm{OH}
$$


When the $V_{G S}$ was kept at constant $0.5 \mathrm{~V}$ value (Figure $4 \mathrm{~B}$ ) $\mathrm{I}_{\mathrm{DS}}$ as a function of $\mathrm{V}_{\mathrm{DS}}$ increased when $\mathrm{pH}$ was reduced. For different ionic strengths plateau of $\mathrm{I}_{\mathrm{DS}}$ reached values of $53.4 \mu \mathrm{A}$ for $\mathrm{pH} 7.01,61.1 \mu \mathrm{A}$ for $\mathrm{pH} 5.00$, and $76.6 \mu \mathrm{A}$ for $\mathrm{pH}$ 3.26. Lower current values for higher $\mathrm{pH}$ clearly indicated lesser ionic activity on the gate surface compared to acidic solution. The obtained results, when the ISFET was analysed at different $\mathrm{pH}$ values, allowed us to confirm the sensitivity of the device to different proton concentrations. The results were in perfect agreement with those described in the literature $[49,50]$.

TNF- $\alpha$ detection was performed on a newly functionalised chip. ImmunoFET was firstly characterised in PBS buffer with no Ags presence, and then, it was incubated with TNF- $\alpha$ Ags spiked in PBS for $30 \mathrm{~min}$. The response characteristics of the ImmunoFET are shown in Figure 5, displaying a positive shift of $\mathrm{V}_{\mathrm{GS}}$ with the binding of TNF- $\alpha$ protein in increasing the concentration buffer.
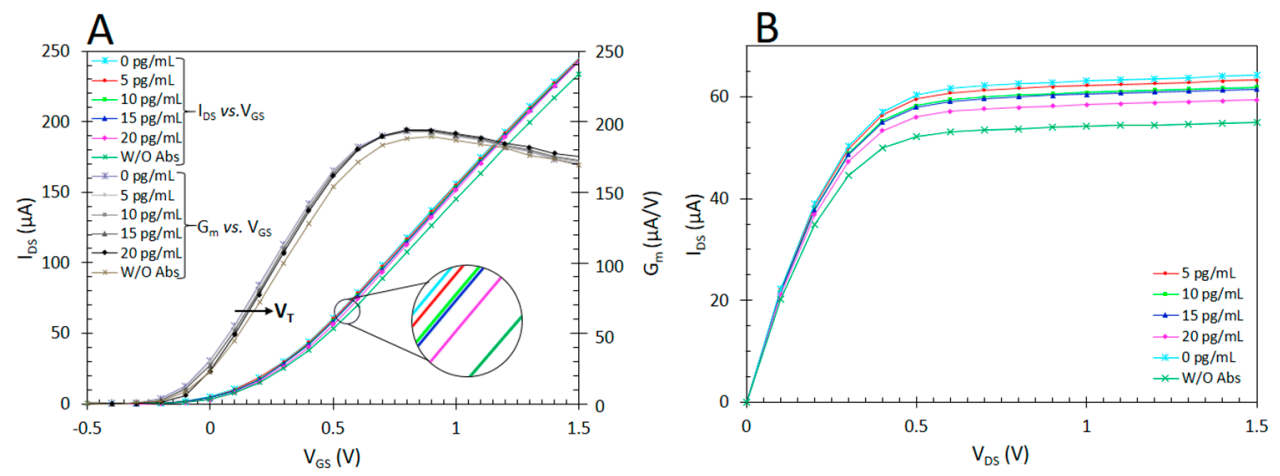

Figure 5. ImmunoFET characteristics for TNF- $\alpha$ detection in phosphate buffer saline (PBS) solution under various TNF- $\alpha$ concentrations: (A) electrical characteristics ( $\mathrm{I}_{\mathrm{DS}}$ vs. $\mathrm{V}_{\mathrm{GS}}$ ) of the ImmunoFET at constant $\mathrm{V}_{\mathrm{DS}}$ value (0.5 V); (B) output characteristics ( $\mathrm{I}_{\mathrm{DS}}$ vs. $\mathrm{V}_{\mathrm{DS}}$ ) of the ImmunoFET under constant $\mathrm{V}_{\mathrm{GS}}$ value $(0.5 \mathrm{~V})$.

After Abs functionalisation, the extracted $\mathrm{V}_{\mathrm{T}}$ shifted to negative values, when compared to the ImmunoFET measurements without Abs functionalisation. This allows us to confirm successful Abs integration on the gate surface. However, this shift of $V_{T}$ values increased again with the rising concentration of antigens (Figure 5A), suggesting that due to the specific interaction between the anti-TNF- $\alpha$ mAbs and their corresponding Ags, gate potential is altered when more Ags are captured by Abs. This was further confirmed by performing the analyses of $I_{D S}$ dependency on the $V_{D S}$ (Figure $5 B$ ). The plateau of $I_{D S}$ current decreased from the initial $61.0 \mu \mathrm{A}$ for ImmunoFET before the incubation with TNF- $\alpha$ Ags to a value of $56.2 \mu \mathrm{A}$ for ImmunoFET after the last incubation at $20 \mathrm{pg} / \mathrm{mL}$ of TNF- $\alpha$ Ags. The obtained results suggest that in the PBS solution the TNF- $\alpha$ proteins are negatively charged, thus the $\mathrm{V}_{\mathrm{T}}$ increases with the rising concentration of Ags are similar to the results obtained previously for the ISFET characterization at different $\mathrm{pH}$ values.

Interference study for ImmunoFET immobilized with anti-TNF- $\alpha$ mAbs were performed to investigate the selectivity for TNF- $\alpha$ protein. The $\Delta V_{T}$ (change in threshold voltage) for various concentrations was calculated by subtracting $V_{T}$ obtained after the incubation in Ags solution by the initial $V_{T}$ value of ImmunoFET (referred as $0 \mathrm{pg} / \mathrm{mL}$ value in the Figure 5 graphs) before. The preliminary results for different biomarkers, which could be found in saliva as HF biomarkers, are shown in Figure 6. The change in threshold voltage for TNF- $\alpha$ protein is clearly dependant on the concentration. It can be seen that the $\Delta \mathrm{V}_{\mathrm{T}}$ approximately linearly increases with the rising amount of antigen present during the incubation step with ImmunoFET. However, changes in threshold voltage have also been observed after incubation of the ImmunoFET into solutions containing NT-proBNP, cortisol, and IL-10. Nevertheless, the changes in the threshold voltage observed due to these biomarkers were random and not influenced by the concentration of the specific biomarker, as it can be seen from Figure 6. Therefore, these signals from interfering molecules can be attributable to adsorption phenomena occurring on the ImmunoFET surface. A possible 
explanation might be that the remaining hydroxyl groups after functionalization may limit the sensor response to the targeted biomarker [51]. The incubation step in $\mathrm{Et}^{-\mathrm{NH}_{2}}$ had to cap unreacted chains of TESUD to prevent nonspecific bonding at the detection stage, since ethanolamine is one of the most commonly used blocking agents for protein coupling via amino groups. Further experiments on the use of different blocking agents (i.e., triethylene glycol monoamine [52]) can be carried out for both reducing unspecific absorption phenomena and improving selective detection of target HF biomarkers.

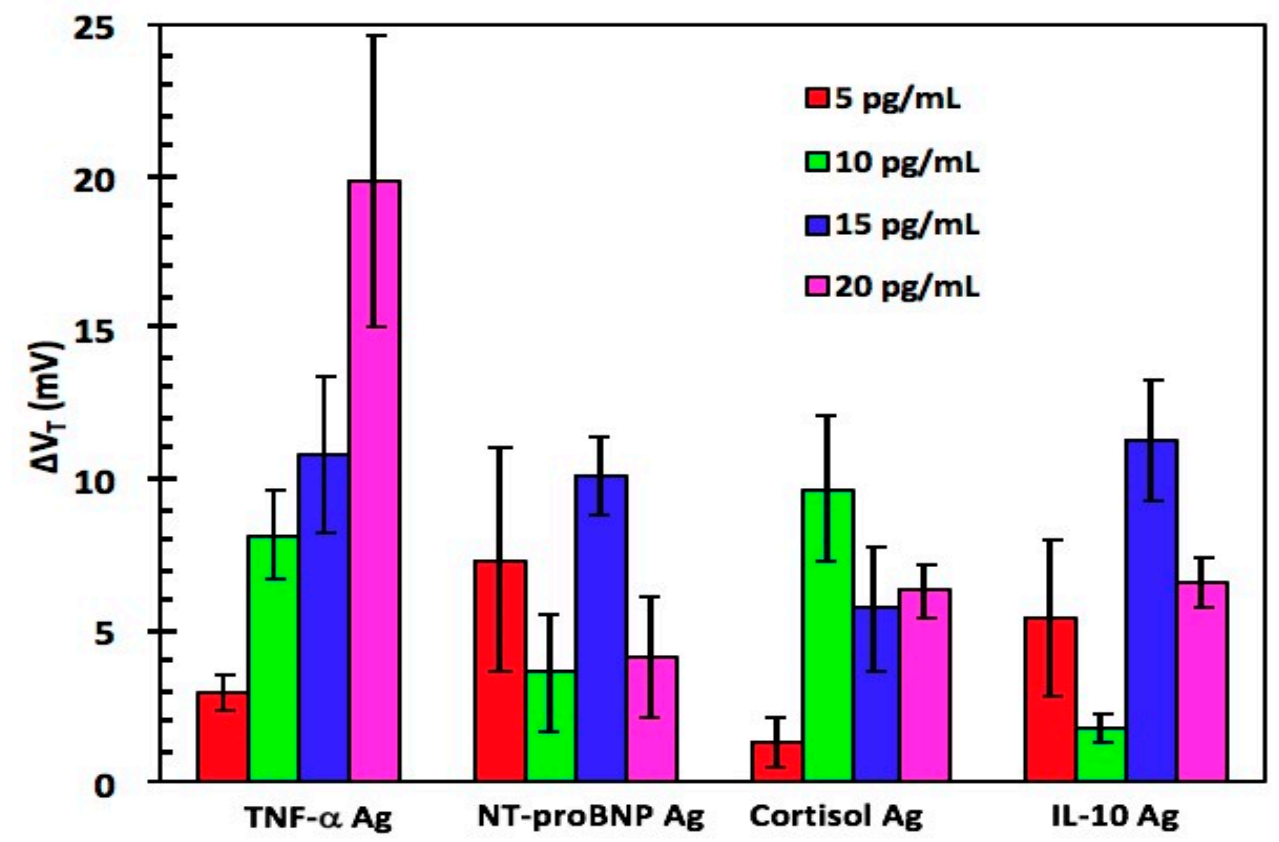

Figure 6. Interference study of $\Delta \mathrm{V}_{\mathrm{T}}$ of ImmunoFET with immobilized anti-mTNF- $\alpha$ for TNF- $\alpha$, NT-proBNP, cortisol, and IL-10 detection.

The detection of TNF- $\alpha$ was further investigated by changing the matrix of Ags. Instead of diluting TNF- $\alpha$ proteins in PBS for the incubation with ImmunoFET, AS was used. Transfer curves of TNF- $\alpha$ antigen detection in AS are presented in Figure 7. It was observed that the change in the matrix influences the obtained signal. From both, the $\mathrm{I}_{\mathrm{DS}}$ dependence on the $\mathrm{V}_{\mathrm{GS}}$ (Figure 7A) and on $\mathrm{V}_{\mathrm{DS}}$ (Figure 7B) observed signal was the opposite compared to incubation in PBS solution.

The plateau shift of $\mathrm{I}_{\mathrm{DS}}$ dependence on the $\mathrm{V}_{\mathrm{DS}}$ was observed to be lower compared to measurements in PBS, the change being only by $0.5 \mu \mathrm{A}$ between the reference and highest concentration of Ags in AS. Similar to the results shown in Figure 5, functionalisation of ImmunoFET with antibodies caused the $V_{T}$ to shift to negative values. However, the $V_{T}$ continued to shift to negative values with the rising concentration of TNF- $\alpha$ protein in AS, contrary to $V_{T}$ for TNF- $\alpha$ diluted in PBS. Nevertheless, the absolute values of the $\Delta V_{T}$ shift remained approximately the same (Figure 8). A similar influence of the change in matrix on the signal direction was already observed by Pulikkathodi et al. [53], who obtained an opposite response of circulating tumour cell detection in PBS and cell culture mediums. The author and his co-authors observed that this influence is due to divalent cation $\left(\mathrm{Ca}^{2+}\right.$ and $\mathrm{Mg}^{2+}$ ) presence in the culture cell medium. They noted that the response is greatly dependant on the concentration of ions $\mathrm{Ca}^{2+}$ and $\mathrm{Mg}^{2+}$ with which the trans-membrane proteins interact, changing the potential of the cell membrane. Therefore, it is likely that $\mathrm{Ca}^{2+}$ presence in AS may interact with TNF- $\alpha$ proteins, charging them positively, thus inducing inverse response when compared to PBS solution without $\mathrm{Ca}^{2+}$. 

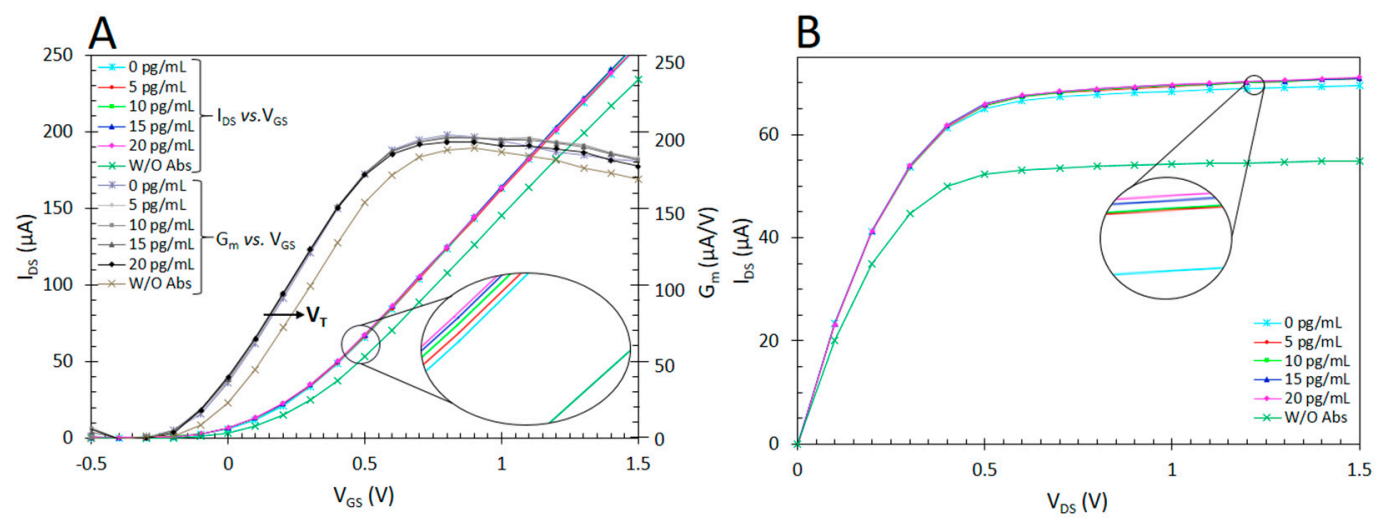

Figure 7. ImmunoFET characteristics for TNF- $\alpha$ detection in artificial saliva under various TNF- $\alpha$ concentration: (A) electrical characteristics ( $I_{D S}$ vs. $V_{G S}$ ) of the ImmunoFET at constant $V_{D S}$ Value $(0.5 \mathrm{~V})$; (B) output characteristics ( $I_{D S}$ vs. $\left.V_{D S}\right)$ of the ImmunoFET under constant $\mathrm{V}_{\mathrm{GS}}$ value $(0.5 \mathrm{~V})$.

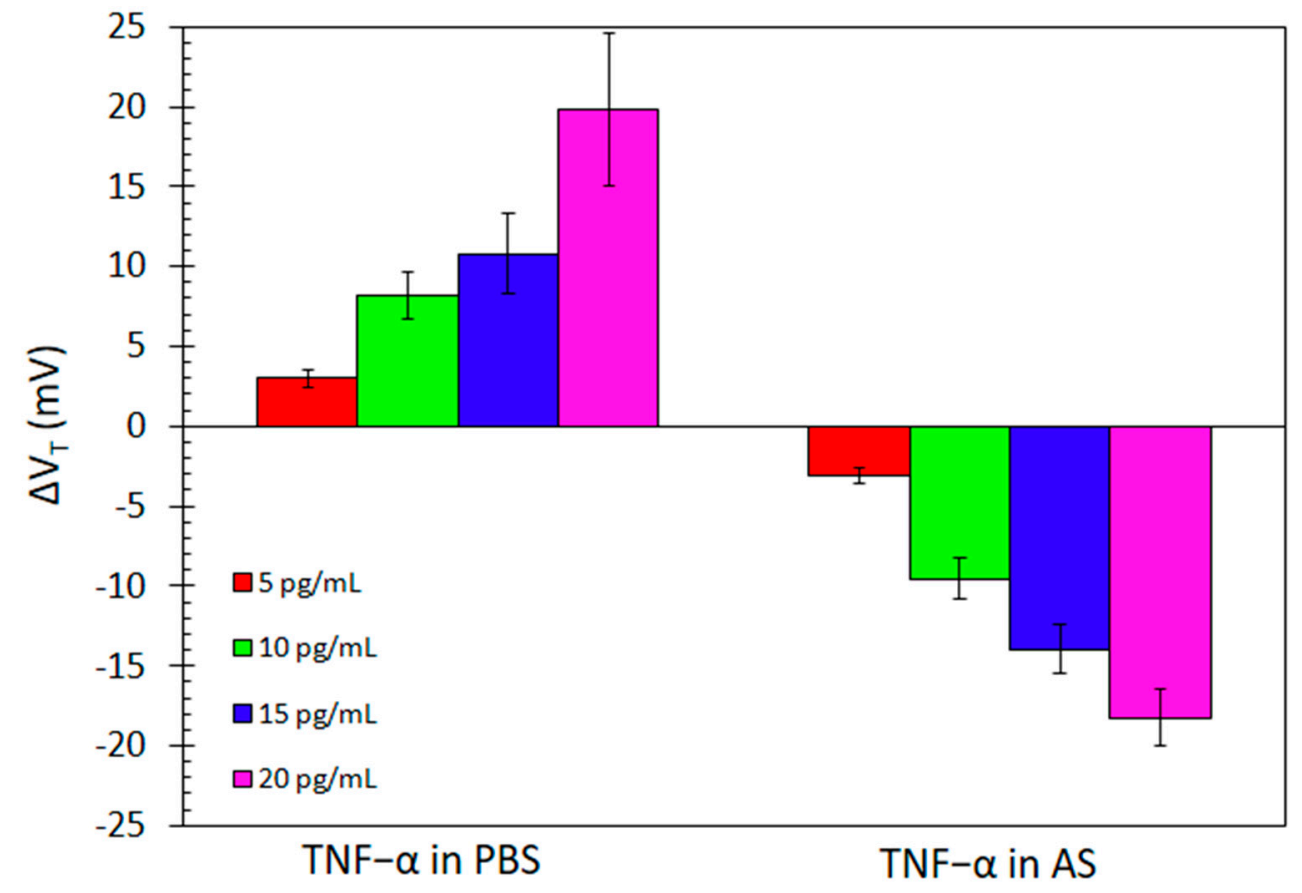

Figure 8. Comparison of $\Delta \mathrm{V}_{\mathrm{T}}$ of ImmunoFET with immobilized anti-TNF- $\alpha$ mAb for TNF- $\alpha$ detection in PBS and in artificial saliva (AS) under various concentrations.

The comparison between electrical measurements performed in this work and other similar techniques based on electrochemical signal measurement is shown in Table 1. It should be noted that other established systems show a significantly lower limit of detection values. Nevertheless, even though lower concentrations than $5 \mathrm{pg} / \mathrm{mL}$ were not tested, the ImmunoFET sensor system in this work provides the ability to detect TNF- $\alpha$ antigens for the detection of HF. Moreover, this system has facile use and size and strong potential as a point of care testing system. 
Table 1. Comparison of different electrochemical immunosensors for TNF- $\alpha$ detection.

\begin{tabular}{ccccc}
\hline Technique & Analyte & Linear Range & LOD & Reference \\
\hline Impedimetric & AS & $1-15 \mathrm{pg} / \mathrm{mL}$ & $1 \mathrm{pg} / \mathrm{mL}$ & {$[54]$} \\
Mott shottcky & AS & $1-30 \mathrm{pg} / \mathrm{mL}$ & $1 \mathrm{pg} / \mathrm{mL}$ & {$[18]$} \\
Amperometry & AS & $1-30 \mathrm{pg} / \mathrm{mL}$ & $1 \mathrm{pg} / \mathrm{mL}$ & {$[11]$} \\
Amperometry & AS & $1-15 \mathrm{pg} / \mathrm{mL}$ & $0.3 \mathrm{pg} / \mathrm{mL}$ & {$[16]$} \\
Electrical measurement & AS & $5-20 \mathrm{pg} / \mathrm{mL}$ & $5 \mathrm{pg} / \mathrm{mL}$ & This work \\
\hline
\end{tabular}

Abbrevations: AS, artificial saliva; LOD, limit of detection.

\section{Conclusions}

In this work, ImmunoFET for the detection of TNF- $\alpha$ protein was developed by immobilizing monoclonal anti-TNF- $\alpha$ antibodies onto the gate surface made of $\mathrm{Si}_{3} \mathrm{~N}_{4}$. The performance of the biosensor was investigated by measuring the shift in the threshold voltage of the gate and the drain-to-source current. Analyses of the electrical characterization of ImmunoFET showed a fast and direct response to the change in antigen concentration. It can be concluded that the developed ImmunoFET based on ISFET with surface modification using anti-TNF- $\alpha$ mAbs is highly sensitive to TNF- $\alpha$ proteins. The shift in $\Delta V_{T}$ for the concentration of TNF- $\alpha$ being in the range of 5 to $20 \mathrm{pg} / \mathrm{mL}$ was approximately linear in both PBS and AS the antigen matrix. While the absolute values of $\Delta \mathrm{V}_{\mathrm{T}}$ shift were approximately the same for both matrixes, the direction of the signal was found to be the opposite. This suggests that proteins possibly interact with ions in the AS, which then changes the electrical charges associated to the molecule, giving the contrary results when compared to PBS measurements. More analyses and improvements are still needed to be performed, such as antibody blocking by BSA, which would allow us to better assess the selectivity of the sensors, and detection in real saliva, which is a much more complex matrix than AS. Nevertheless, the developed ImmunoFET showed great potential for direct and fast detection of TNF- $\alpha$ protein in saliva samples for heart failure diagnosis and monitoring.

Author Contributions: Writing—original draft preparation, D.V.; validation and editing, H.B.H.; formal analysis, F.G.B.; methodology, A.A.; software, F.P.; validation, N.J.-R.; supervision, N.Z.; conceptualization, J.B.; editing, A.E. (Abdelhamid Elaissari); supervision and funding acquisition, A.E. (Abdelhamid Errachid). All authors have read and agreed to the published version of the manuscript.

Funding: We acknowledge the funding through the European Union's Horizon 2020 research and innovation programme entitled "An integrated POC solution for non-invasive diagnosis and therapy monitoring of heart failure patients, KardiaTool" under grant agreement No. 768686. This work made use of the Spanish ICTS network MICRONANOFABS, partially supported by MICINN and the Generalitat de Catalunya thought the TECNIOSpring PLUS program (TECSPR18-1-0042) to F. Palacio.

Institutional Review Board Statement: Not applicable.

Informed Consent Statement: Not applicable.

Data Availability Statement: Raw data is available from the corresponding author.

Conflicts of Interest: The authors declare no conflict of interest.

\section{References}

1. Jessup, M.; Brozena, S. Heart Failure. N. Engl. J. Med. 2003, 348, 2007-2018. [CrossRef] [PubMed]

2. Benjamin, E.J.; Muntner, P.; Alonso, A.; Bittencourt, M.S.; Callaway, C.W.; Carson, A.P.; Chamberlain, A.M.; Chang, A.R.; Cheng, S.; Das, S.R.; et al. Heart Disease and Stroke Statistics-2019 Update: A Report From the American Heart Association. Circulation 2019, 139, e56-e528. [CrossRef] [PubMed]

3. Savarese, G.; Lund, L.H. Global Public Health Burden of Heart Failure. Card Fail. Rev. 2017, 3, 7-11. [CrossRef]

4. Guha, K.; McDonagh, T. Heart Failure Epidemiology: European Perspective. Available online: https://www.ingentaconnect. com/content/ben/ccr/2013/00000009/00000002/art00005 (accessed on 28 October 2019).

5. Schiff, G.D.; Fung, S.; Speroff, T.; McNutt, R.A. Decompensated Heart Failure: Symptoms, Patterns of Onset, and Contributing Factors. Am. J. Med. 2003, 114, 625-630. [CrossRef]

6. Braunwald, E. Biomarkers in Heart Failure. N. Engl. J. Med. 2008, 358, 2148-2159. [CrossRef] 
7. Levine, B.; Kalman, J.; Mayer, L.; Fillit, H.M.; Packer, M. Elevated Circulating Levels of Tumor Necrosis Factor in Severe Chronic Heart Failure. N. Engl. J. Med. 1990, 323, 236-241. [CrossRef]

8. van Kimmenade, R.R.J.; Januzzi, J.L. Emerging Biomarkers in Heart Failure. Clin. Chem. 2012, 58, 127-138. [CrossRef]

9. Wild, D. The Immunoassay Handbook: Theory and Applications of Ligand Binding, ELISA and Related Techniques; Elsevier: Newnes, Australia, 2013; ISBN 978-0-08-097038-7.

10. De Moraes, A.C.M.; Kubota, L.T. Recent Trends in Field-Effect Transistors-Based Immunosensors. Chemosensors 2016, 4, 20. [CrossRef]

11. Barhoumi, L.; Baraket, A.; Bellagambi, F.G.; Karanasiou, G.S.; Ali, M.B.; Fotiadis, D.I.; Bausells, J.; Zine, N.; Sigaud, M.; Errachid, A. A Novel Chronoamperometric Immunosensor for Rapid Detection of TNF- $\alpha$ in Human Saliva. Sens. Actuators B Chem. 2018, 266, 477-484. [CrossRef]

12. Perumal, V.; Hashim, U. Advances in Biosensors: Principle, Architecture and Applications. J. Appl. Biomed. 2014, 12, 1-15. [CrossRef]

13. Luong, J.H.T.; Male, K.B.; Glennon, J.D. Biosensor Technology: Technology Push versus Market Pull. Biotechnol. Adv. 2008, 26, 492-500. [CrossRef] [PubMed]

14. Pohanka, M. Piezoelectric Biosensor for the Determination of Tumor Necrosis Factor Alpha. Talanta 2018, 178, 970-973. [CrossRef] [PubMed]

15. Li, L.; Li, M.; Wang, W.; Zhang, Q.; Liu, D.; Li, X.; Jiang, H. High Sensitivity Determination of TNF- $\alpha$ for Early Diagnosis of Neonatal Infections with a Novel and Reusable Electrochemical Sensor. Sensors 2017, 17, 992. [CrossRef] [PubMed]

16. Barhoumi, L.; Bellagambi, F.G.; Vivaldi, F.M.; Baraket, A.; Clément, Y.; Zine, N.; Ben Ali, M.; Elaissari, A.; Errachid, A. Ultrasensitive Immunosensor Array for TNF- $\alpha$ Detection in Artificial Saliva Using Polymer-Coated Magnetic Microparticles onto Screen-Printed Gold Electrode. Sensors 2019, 19, 692. [CrossRef]

17. Bellagambi, F.G.; Baraket, A.; Longo, A.; Vatteroni, M.; Zine, N.; Bausells, J.; Fuoco, R.; Di Francesco, F.; Salvo, P.; Karanasiou, G.S.; et al. Electrochemical Biosensor Platform for TNF- $\alpha$ Cytokines Detection in Both Artificial and Human Saliva: Heart Failure. Sens. Actuators B Chem. 2017, 251, 1026-1033. [CrossRef]

18. Bahri, M.; Baraket, A.; Zine, N.; Ben Ali, M.; Bausells, J.; Errachid, A. Capacitance Electrochemical Biosensor Based on Silicon Nitride Transducer for TNF- $\alpha$ Cytokine Detection in Artificial Human Saliva: Heart Failure (HF). Talanta 2020, $209,120501$. [CrossRef]

19. Kaisti, M. Detection Principles of Biological and Chemical FET Sensors. Biosens. Bioelectron. 2017, 98, 437-448. [CrossRef]

20. Yuqing, M.; Jianguo, G.; Jianrong, C. Ion Sensitive Field Effect Transducer-Based Biosensors. Biotechnol. Adv. 2003, 21, 527-534. [CrossRef]

21. Chen, H.; Choo, T.K.; Huang, J.; Wang, Y.; Liu, Y.; Platt, M.; Palaniappan, A.; Liedberg, B.; Tok, A.I.Y. Label-Free Electronic Detection of Interleukin-6 Using Horizontally Aligned Carbon Nanotubes. Mater. Des. 2016, 90, 852-857. [CrossRef]

22. Selvanayagam, Z.E.; Neuzil, P.; Gopalakrishnakone, P.; Sridhar, U.; Singh, M.; Ho, L.C. An ISFET-Based Immunosensor for the Detection of $\beta$-Bungarotoxin. Biosens. Bioelectron. 2002, 17, 821-826. [CrossRef]

23. Zhang, Y.; Chen, R.; Xu, L.; Ning, Y.; Xie, S.; Zhang, G.-J. Silicon Nanowire Biosensor for Highly Sensitive and Multiplexed Detection of Oral Squamous Cell Carcinoma Biomarkers in Saliva. Anal. Sci. 2015, 31, 73-78. [CrossRef] [PubMed]

24. Muangsuwan, W.; Promptmas, C.; Jeamsaksiri, W.; Bunjongpru, W.; Srisuwan, A.; Hruanun, C.; Poyai, A.; Wongchitrat, P.; Yasawong, M. Development of an ImmunoFET Biosensor for the Detection of Biotinylated PCR Product. Heliyon 2016, 2 , e00188. [CrossRef] [PubMed]

25. Wu, J.; Dong, M.; Santos, S.; Rigatto, C.; Liu, Y.; Lin, F. Lab-on-a-Chip Platforms for Detection of Cardiovascular Disease and Cancer Biomarkers. Sensors 2017, 17, 2934. [CrossRef] [PubMed]

26. Wu, J.; Dong, M.; Rigatto, C.; Liu, Y.; Lin, F. Lab-on-Chip Technology for Chronic Disease Diagnosis. NPJ Digit. Med. 2018, 1, 1-11. [CrossRef] [PubMed]

27. Rhodus, N.L.; Ho, V.; Miller, C.S.; Myers, S.; Ondrey, F. NF-KB Dependent Cytokine Levels in Saliva of Patients with Oral Preneoplastic Lesions and Oral Squamous Cell Carcinoma. Cancer Detect. Prev. 2005, 29, 42-45. [CrossRef]

28. Pezelj-Ribaric, S.; Prso, I.B.; Abram, M.; Glazar, I.; Brumini, G.; Simunovic-Soskic, M. Salivary Levels of Tumor Necrosis Factor- $\alpha$ in Oral Lichen Planus. Mediat. Inflamm. 2004, 13, 131-133. [CrossRef]

29. Bellagambi, F.G.; Degano, I.; Ghimenti, S.; Lomonaco, T.; Dini, V.; Romanelli, M.; Mastorci, F.; Gemignani, A.; Salvo, P.; Fuoco, R.; et al. Determination of Salivary $\alpha$-Amylase and Cortisol in Psoriatic Subjects Undergoing the Trier Social Stress Test. Microchem. J. 2018, 136, 177-184. [CrossRef]

30. Bellagambi, F.G.; Lomonaco, T.; Salvo, P.; Vivaldi, F.; Hangouët, M.; Ghimenti, S.; Biagini, D.; Di Francesco, F.; Fuoco, R.; Errachid, A. Saliva Sampling: Methods and Devices. An Overview. TrAC Trends Anal. Chem. 2020, 124, 115781. [CrossRef]

31. Biagini, D.; Lomonaco, T.; Ghimenti, S.; Fusi, J.; Cerri, E.; De Angelis, F.; Bellagambi, F.G.; Oger, C.; Galano, J.M.; Bramanti, E.; et al. Saliva as a Non-Invasive Tool for Monitoring Oxidative Stress in Swimmers Athletes Performing a VO2max Cycle Ergometer Test. Talanta 2020, 216, 120979. [CrossRef]

32. Ghimenti, S.; Lomonaco, T.; Bellagambi, F.G.; Biagini, D.; Salvo, P.; Trivella, M.G.; Scali, M.C.; Barletta, V.; Marzilli, M.; Di Francesco, F; i et al. Salivary Lactate and 8-Isoprostaglandin F $2 \alpha$ as Potential Non-Invasive Biomarkers for Monitoring Heart Failure: A Pilot Study. Sci. Rep. 2020, 10, 7441. [CrossRef] 
33. Lomonaco, T.; Ghimenti, S.; Biagini, D.; Bramanti, E.; Onor, M.; Bellagambi, F.G.; Fuoco, R.; Di Francesco, F. The Effect of Sampling Procedures on the Urate and Lactate Concentration in Oral Fluid. Microchem. J. 2018, 136, 255-262. [CrossRef]

34. Bartekova, M.; Radosinska, J.; Jelemensky, M.; Dhalla, N.S. Role of Cytokines and Inflammation in Heart Function during Health and Disease. Heart Fail. Rev. 2018, 23, 733-758. [CrossRef] [PubMed]

35. Gaggin, H.K.; Januzzi, J.L. Biomarkers and Diagnostics in Heart Failure. Biochim. Biophys. Acta (BBA) Mol. Basis Dis. 2013, 1832, 2442-2450. [CrossRef] [PubMed]

36. Ibrahim, N.; Januzzi, J.L. The Potential Role of Natriuretic Peptides and Other Biomarkers in Heart Failure Diagnosis, Prognosis and Management. Expert Rev. Cardiovasc. Ther. 2015, 13, 1017-1030. [CrossRef]

37. Magnussen, C.; Blankenberg, S. Biomarkers for Heart Failure: Small Molecules with High Clinical Relevance. J. Intern. Med. 2018, 283, 530-543. [CrossRef]

38. Nadar, S.K.; Shaikh, M.M. Biomarkers in Routine Heart Failure Clinical Care. Card Fail. Rev. 2019, 5, 50-56. [CrossRef]

39. Tamariz, L.; Hare, J.M. Inflammatory Cytokines in Heart Failure: Roles in Aetiology and Utility as Biomarkers. Eur. Heart J. 2010, 31, 768-770. [CrossRef]

40. Baraket, A.; Lee, M.; Zine, N.; Yaakoubi, N.; Bausells, J.; Errachid, A. A Flexible Electrochemical Micro Lab-on-Chip: Application to the Detection of Interleukin-10. Microchim. Acta 2016, 183, 2155-2162. [CrossRef]

41. Baraket, A.; Lee, M.; Zine, N.; Sigaud, M.; Yaakoubi, N.; Trivella, M.G.; Zabala, M.; Bausells, J.; Jaffrezic-Renault, N.; Errachid, A. Diazonium Modified Gold Microelectrodes onto Polyimide Substrates for Impedimetric Cytokine Detection with an Integrated $\mathrm{Ag} / \mathrm{AgCl}$ Reference Electrode. Sens. Actuators B Chem. 2013, 189, 165-172. [CrossRef]

42. Caballero, D.; Martinez, E.; Bausells, J.; Errachid, A.; Samitier, J. Impedimetric Immunosensor for Human Serum Albumin Detection on a Direct Aldehyde-Functionalized Silicon Nitride Surface. Anal. Chim. Acta 2012, 720, 43-48. [CrossRef]

43. Caballero, D.; Samitier, J.; Bausells, J.; Errachid, A. Direct Patterning of Anti-Human Serum Albumin Antibodies on AldehydeTerminated Silicon Nitride Surfaces for HSA Protein Detection. Small 2009, 5, 1531-1534. [CrossRef] [PubMed]

44. Ben Halima, H.; Zine, N.; Gallardo-González, J.; Aissari, A.E.; Sigaud, M.; Alcacer, A.; Bausells, J.; Errachid, A. A Novel Cortisol Biosensor Based on the Capacitive Structure of Hafnium Oxide: Application for Heart Failure Monitoring. In Proceedings of the 2019 20th International Conference on Solid-State Sensors, Actuators and Microsystems \& Eurosensors XXXIII (TRANSDUCERS \& EUROSENSORS XXXIII), Berlin, Germany, 23-27 June 2019; pp. 1067-1070. [CrossRef]

45. Lee, M.; Zine, N.; Baraket, A.; Zabala, M.; Campabadal, F.; Caruso, R.; Trivella, M.G.; Jaffrezic-Renault, N.; Errachid, A. A Novel Biosensor Based on Hafnium Oxide: Application for Early Stage Detection of Human Interleukin-10. Sens. Actuators B Chem. 2012, 175, 201-207. [CrossRef]

46. Castellarnau, M.; Zine, N.; Bausells, J.; Madrid, C.; Juárez, A.; Samitier, J.; Errachid, A. ISFET-Based Biosensor to Monitor Sugar Metabolism in Bacteria. Mater. Sci. Eng. C 2008, 28, 680-685. [CrossRef]

47. Castellarnau, M.; Zine, N.; Bausells, J.; Madrid, C.; Juárez, A.; Samitier, J.; Errachid, A. Integrated Microanalytical System Based on Electrochemical Detection and Cell Positioning. Mater. Sci. Eng. C 2006, 26, 405-410. [CrossRef]

48. Harame, D.L.; Bousse, L.J.; Shott, J.D.; Meindl, J.D. Ion-Sensing Devices with Silicon Nitride and Borosilicate Glass Insulators. IEEE Trans. Electron. Devices 1987, 34, 1700-1707. [CrossRef]

49. Castellarnau, M.; Zine, N.; Bausells, J.; Madrid, C.; Juárez, A.; Samitier, J.; Errachid, A. Integrated Cell Positioning and Cell-Based ISFET Biosensors. Sens. Actuators B Chem. 2007, 120, 615-620. [CrossRef]

50. Errachid, A.; Ivorra, A.; Aguiló, J.; Villa, R.; Zine, N.; Bausells, J. New Technology for Multi-Sensor Silicon Needles for Biomedical Applications. Sens. Actuators B Chem. 2001, 78, 279-284. [CrossRef]

51. Stoop, R.; Wipf, M.; Müller, S.; Bedner, K.; Wright, I.A.; Martin, C.; Constable, E.; Fu, W.; Tarasov, A.; Calame, M.; et al. Competing surface reactions limiting the performance of ion-sensitive field-effect transistors. Sens. Actuators B Chem. 2015, 220, 500-507. [CrossRef]

52. Chapman, R.G.; Ostuni, E.; Yan, L.; Whitesides, G.M. Preparation of mixed self-assembled monolayers (SAMs) that resist adsorption of proteins using the reaction of amines with a SAM that presents interchain carboxylic anhydride groups. Langmuir 2000, 16, 6927-6936. [CrossRef]

53. Pulikkathodi, A.K.; Sarangadharan, I.; Hsu, C.-P.; Chen, Y.-H.; Hung, L.-Y.; Lee, G.-Y.; Chyi, J.-I.; Lee, G.-B.; Wang, Y.-L. Enumeration of Circulating Tumor Cells and Investigation of Cellular Responses Using Aptamer-Immobilized AlGaN/GaN High Electron Mobility Transistor Sensor Array. Sens. Actuators B Chem. 2018, 257, 96-104. [CrossRef]

54. Longo, A.; Baraket, A.; Vatteroni, M.; Zine, N.; Baussells, J.; Roger, F.; Di Francesco, F.; Karanasiou, G.S.; Fotiadis, D.I.; Menciassi, A.; et al. Highly Sensitive Electrochemical BioMEMS for TNF- $\alpha$ Detection in Humansaliva: Heart Failure. Procedia Eng. 2016, 168, 97-100. [CrossRef] 